\title{
Media Puzzle Kartu Angka Meningkatkan Kemampuan Operasi Pengurangan bagi Anak Diskalkulia
}

\author{
Sevira Liza Reafani ${ }^{1}$, Fatmawati $^{2}$ Irdamurni $^{3}$ \\ ${ }^{123}$ Universitas Negeri Padang, Indonesia \\ Email: seviraliza@gmail.com
}

\section{INFORMASI ARTIKEL}

terkirim 26 Januari 2018

Revisi dari 27 January 2018

Diterima 29 Januari 2018

\section{Kata kunci:}

Media Puzzle Kartu Angka,

Kemampuan Pengurangan,

Diskalkulia

\begin{abstract}
ABSTRAK
Berdasarkan permasalahan yang ditemukan di kelas IV di SD N 01 Limau Manis Padang beberapa anak memiliki nilai rendah dalam kemampuan operasi pengurangan. Saat mengerjakan soal pengurangan, anak masih salah dalam mengurangi kecil ke besar. Ketika mengurangi dari kecil ke besar dibalik menjadi besar ke kecil tanpa meminjam. Anak diskalkulia memiliki kelemahan dalam belajar matematika. Kesulitan yang dimiliki anak tentang pengurangan adalah konsep dasar matematika. Penting bagi anak untuk memahami konsep pengurangan. Salah satu komponen penting dalam pembelajaran yaitu media pembelajaran. Saat pembelajaran, guru dapat menggunakan media dalam memberikan materi termasuk belajar matematika. Alternatif yang harus dilakukan untuk membantu meningkatkan kemampuan pengurangan anak diskalkulia, salah satunyamedia puzzle kartu angka. Media puzzle kartu angka adalah permainan bongkar padang diadaptasi dari materi pengurangan puluhan dengan teknik meminjam. Hasil penelitian ini menunjukkan media puzzle kartu angka efektif untuk meningkatkan kemampuan pengurangan bagi anak diskalkulia kelas IV SD N 01 Limau Manis Padang.
\end{abstract}

\section{Pendahuluan}

Pentingnya matematika dalam kehidupan sehari-hari terlihat pada pengaplikasian dalam kehidupan seperti jual beli, menghitung, mengukur dan sebagainya. Sesuai dengan Turmudi (2008:3) matematika berkaitan erat dengan kehidupan sehari-hari sehingga dengan segera siswa akan mampu menerapkan matematika dalam konteks yang berguna bagi siswa, baik dalam dunia kehidupannya ataupun dalam dunia kerja kelak. Penggunaan matematika dalam kehidupan sehari-hari menuntut siswa untuk menguasai konsep dasar dari matematika tersebut. Penempatan konsep dasar matematika menjadi keharusan untuk siswa. Studi penelitian oleh Shadiq tahun 2004 menyatakan bahwa matematika memiliki peranan yang sangat penting, tidak mungkin bagi seseorang untuk hidup dibagian bumi ini pada abad ke-20 tanpa sedikitpun memanfaatkan matematika. Penelitian tersebut mendukung bahwa memang sangat penting matematika dalam kehidupan sehari-hari.

Berdasarkan hasil studi pendahuluan yang peneliti lakukan dikelas IV SD N 01 Limau Manis Padang, ketika mengamati anak-anak dalam mengerjakan soal matematika terlihat beberapa anak masih keliru. Untuk soal penjumlahan, anak sudah dapat mengerjakannya dengan baik, sedangkan untuk pengurangan yang masih terdapat kekeliruan. Saat mengerjakan soal pengurangan satuan, anak sudah bisa lalu saat pengurangan puluhan dengan teknik meminjam, dalam perhitungannya masih keliru.Saat mengamati terlihat ada beberapa anak yang masih kesulitan dalam mengerjakan soal pengurangan dengan meminjam. Mereka mendapatkan nilai terendah untuk soal matematika. Ketika mengerjakan soal pengurangan dari kecil ke besar, yang anak lakukanmembalik angka menjadi dari besar ke kecil, sehingga tidak ada proses meminjam. Contohnya seperti $6-9$ oleh anak dibalik menjadi 9 -6 sehingga anak mendapat hasil 3 , tanpa adanya teknik meminjam.

Untuk materi pengurangan telah diajarkan sebagai materi pembelajaran matematika dikelas II, sedangkan anak sudah duduk dikelas IV dengan materi yang dituntut ialah mengenai perkalian, pembagian dan operasi hitung campuran. Materi pengurangan yang kelas II saja anak masih keliru, untuk bisa pembagian maka anak harus menguasai pengurangan terlebih dahulu. Pengurangan merupakan salah satu dari empat operasi dasar aritmatika,dan pada prinsipnya merupakan kebalikan dari operasi penjumlahan. Operasi pengurangan merupakan materi dasar yang harus anak kuasai dalam pembelajaran matematika. Pengaplikasian dalam kehidupan sehari-hari untuk pengurangan banyak dipakai. Untuk melihat lebih jauh, maka dilakukan asesmen kepada tujuh anak yang mendapatkan nilai terendah dalam identifikasi. Asesmen ini dilakukan untuk melihat sejauh mana kemampuan anak mengenai operasi itung pengurangan dengan teknik meminjam. Hasil dari asesmen kemampuan pengurangan dengan teknik meminjam, semua anak memperoleh nilai 0 . Penyebabnya karena operasi hitung pengurangan yang anak lakukan keliru.

Saat pendidikan dasar anak memperoleh ilmu atau pengetahuan dasar dari mata pelajaran yang akan diajarkan. Setiap jenjangnya memiliki kompetensi yang berbeda-beda. Sesuai dengan buku ajar matematika, seperti untuk kelas IV materi yang dituntut bagi anak ialah terkait perkalian, pembagian dan operasi hitung campuran. Anak belajar mulai dari penjumlahan, lalu pengurangan hingga perkalian dan pembagian. Merupakan contoh bahwa materi pembelajaran matematika itu selalu terkait seperti untuk bisa pembagian anak harus menguasai pengurangan, walaupun yang dituntut bagi anak itu berbeda-beda setiap jenjangnya. Penyampaian materi yang dilakukan oleh guru disampaikan saat proses belajar mengajar terjadi. Perencanaan proses pembelajaran harus matang dibuat oleh guru agar pembelajaran dapat terjadi dengan efektif, beberapa komponen perencanaan pembelajaraan ialah adanya indikator, adanya tujuan pembelajaran, metode, startegi, media dan penilaian dalam pembelajaran. Ketika melakukan wawancara, dalam pembelajaran yang dilakukan guru kelas di kelas IV, hanya menggunakan metode ceramah, untuk penggunaan media, tidak ada media pembantu lain hanya papan tulis saja yang digunakan oleh guru. Sedangkan anak yang dididik dikelas IV hampir 30 anak.

Terkait proses belajar mengajar, salah satu komponennya yaitu media pembelajaran. Media merupakan alat, sarana perantara dan penghubung untuk menyampaikan pesan. Banyak sekali jenis-jenis media, secara umum, ada media tiga dimensi dan media dua dimensi. Salah satu contoh media dua dimensi yaitu media puzzle yang berupa seperti permainan bersifat edukatif. Media puzzle ini juga digunakan dalam beberapa penelitian, seperti berdasarkan hasil penelitian Sofa Shoffan tahun 2015, pembelajaran yang menggunakan media puzzle cerdas membawa perubahan pada hasil belajar anak, 
seperti meningkatkan kemampuan kognitif anak dalam berhitung 1- 20.Sejalan dengan itu hasil penelitian oleh Prabowo tahun 2012 menyebutkan bahwa implikasi kesimpulan penelitiannya yaitu penggunaan media puzzle bagi guru akan meningkatkan hasil belajar siswa, meningkatkan antusias siswa dalam belajar, meningkatkan kerjasama dan menuntut guru untuk kreatif.

Media puzzle dapat dimodifikasi sesuai dengan kebutuhan guru seperti media puzzle kartu angka. Media puzzle kartu angka merupakan puzzle yang berisikan kartu angka- angka untuk membantu anak dalam mengerjakan soal pengurangan, terdiri dari dua bagian yaitu bagian soal dan bagian penyelesaian. Media ini berdasarkan pengurangan dengan metode bersusun kebawah pendek dan metode bersusun kebawah panjang sesuai dengan nilai tempat. Pengunaan anak akan menempelkan kartu angka pada papan puzzle sesuai dengan soal yang diberikan oleh guru dan penyelesaian dari soal tersebut. Media ini beradaptasi dari sebuah permainan yang dapat menarik minat anak juga karena belum pernah digunakan oleh guru. Adaptasi dari media puzzle kartu angka berdasarkan pada materi yang diajarkan oleh guru, ada didalam buku pembelajaran matematika terkait pengrangan dengan meminjam. Maka dari itu lebih memudahkan untuk menyampaikan materi yang ingin disampaikan kepada anak. Adanya soal lalu, penjabaran angka sesuai dengan nilai tempatnya, hingga adanya proses peminjaman, pengurangan bahkan penjumlahan singkat.

Dalam penggunaan media dapat ditinjau juga dari segi peserta didik. Peserta didik disini tidak terkecuali anak-anak berkebutuhan khusus. Anak-anak yang memiliiki kebutuhan khusus dengan memerlukan layana khusus juga berhak memperoleh pendidikan. Anak berkebutuhan khusus adalah anak yang membutuhkan layanan yang khusus dalam menjalankan kehidupan sehari-harinya termasuk dalam hal pendidikan. Ketika pembelajaran anak membutuhkan adanya layanan khusus seperti media khusus, metode tambahkan, strategi yang baru dalam belajar, bertujuan agar anak dapat lebih mudah memahami materi yang diajarkan. Salah satu jenis dari anak berkebutuhan khusus yaitu anak berkesulitan belajar, anak yang memiliki kelemahan pada akademiknya sehingga berdampak kepada hasil belajar anak seperti pada membaca, menulis, dan berhitung. Untuk anak yang memiliki kesulitan berhitung biasa disebut dengan diskalkulia. Anak kesulitan dalam memahami simbol serta pemahaman anak yang keliru terhadap konsep dari matematika menyebabkan anak memiliki hasil belajar yang rendah.

Diskalkulia merupakan kondisi yang ditunjukan dengan adanya kelemahan pada anak dalam menyelesaikan soal-soal mengenai pembelajaran berhitung seperti, penjumlahan, pengurangan, dan sebagainya. Diskalkulia berdasarkan studi terkini oleh Shalev, Manor \& Gross-Tsur tahun 2005 menjelaskan bahwa diskalkulia merupakan kondisi kesulitan belajar yang berlangsung lama atu terus menerus pada banyak anak; lebih dari separuh anakanak masih mendapatkan niai yang jelek dalam matematika ketika mereka sampaik ke kelas lima. Selanjutnya penelitian oleh Suryani tahun 2010 diskalkulia dikelompokan berdasarkan tingkatan, karena kemampuan berhitung terdiri dari kemampuan dasar sampai kemampuan lanjut. Diskalkulia meliputi pada 1) kemampuan dasar berhitung, 2) kemampuan dalam menentukan nilai temapat, 3) kemampuan melakukan operasi penjumlahan dengan atau tanpa teknik menyimpan dan pengurangan dengan atau tanpa teknik meminjam, 4) kemampuan memahami konsep perkalian dan pembagian. Anak diskalkulia pada penelitian ini memiliki kekeliruan pada konsep pengurangan dengan teknik meminjam, sehingga cara operasi hitung anak yang menjadi salah.

Persepsi anak untuk pembelajaran matematika memandang sulit untuk belajarnya, sehingga anak malas belajar apalagi untuk mengulang materi yang diajarkan. Terkait dengan kesulitan yang anak alami, guru pendamping khusus membantu anak dalam memahami materi yang tidak anak kuasai. Ketika memberikan pelayanan kepada anak, guru pendamping khusus (GPK) hanya dengan tatap muka, tanpa ada media sebagai alat untuk membantu anak, diberikan remedia, dan penjelasan ulang mengenai yang anak belum bisa. Untuk membantu anak dalam mengatasi kesulitan belajar matematika, terletak pada cara menyampaikan, belajar matematika dimulai dari hal yang konkrit untuk memudahkan anak memahami materi yang diajarkan apalagi untuk pemantapan konsep bagi anak. Didukung oleh penelitian yang dilakukan oleh Aini tahun 2015 menunjukkan ketika pembelajaran menggunakan media konkrit salah satunya yaitu pengalaman dan kesan dalam belajar lebih melekat pada diri peserta didik.

Masalah mengenai kesulitan anak dalam kemampuan pengurangan harus diatasi sejak dini, apalagi jika ditinjau dari pentingnya matematika dalam kehidupan dan pengurangan juga merupakan dari dasar pembelajaran matematika. Saat pembelajaran salah satu komponen yang menarik minat anak untuk belajar ialah media pembelajaran, sesuai dengan bahasan diatas mengenai media puzzle kartu angka, sehingga sepertinya dapat digunakan dalam membantu pembelajaran anak diskalkulia. Untuk membantu mengatasi kesulitan anak dalam berhitung pengurangan dengan teknik meminjam sehingga diuji melalui media puzzle kartu angka, maka penulis meneliti, efektivitas media puzzle kartu angka dalam meningkatkan kemampuan operasi pengurangan bagi anak Diskalkulia kelas IV SD N 01 Limau Manis Padang.

\section{Metode}

Penelitian ini dilakukan menggunakan salah satu pendekatan penelitian ialah pendekatan kuantitaif. Jenis penelitian yang digunakan ialah penelitian eksperimen, melakukan suatu kegiatan percobaan guna meneliti dua hal yang dibandingkan setelah pemberian perlakuan atau percobaan tersebut. Penelitian eksperimen dibagi menjadi dua yaitu pre-experiment atau biasa disebutquasy experiment dan true experiment. Penelitian eksperimen yang digunakan dalam penelitian iniyaitu dengan jenis quasy experiment atau jenis penelitian pre-experiment dengan one gorup pretest-posttest design. Sesuai dengan desain penelitian yaitu one gorup pretest-posttest design, penelitian akan dilaksanakan pada satu kelompok, kelompok kontrol menjadi kelompok eksperimen. Penelitian ini akan menggunakan dua kali observasi, observasi pertama yaitu pretest $\left(\mathrm{O}_{1}\right)$, tes awal untuk mengetahui kemampuan awal anaksebelum diberikan perlakuan, selanjutnya perlakuan diberikan menggunakan media puzzle kartu angka, dan observasi kedua, pemberiaan tes untuk melihat kemampuan anak setelah diberikan yaitu post-test $\left(\mathrm{O}_{2}\right)$.

Variabel dalam penelitian ini ada dua variabel yaitu variabel bebas dan variabel terikat. Adapun variabel terikat dalam penelitian ini yaitu kemampuan operasi pengurangan sedangkan untuk variabel bebas adala media puzzle kartu angka. Defenisi operasional variabel juga ditinjau dari kedua variabel dalam penelitian ini. Media puzzle kartu angka yang digunakan penelitian puzzle yang telat dimodifikasi sesuai dengan materi pengurangan dengan teknik meminjam yang diajarkan oleh guru, dibantu dengan kartu angka sebagai kepingan puzzle. Kemampuan operasi pengurangan, anak mampu melakukan menempatkan nilai angka sesuai dengan nilai tempatnya dan melakuan proses peminjaman serta pengurangan. Populasi pada penelitian ini adalahsemua anak diskalkulia kelas IV di SD N 01 Limau Manis Padang. Menurut Arikunto (2013:95) menyatakan saat jumlah populasi atau subjek penelitian kurang dari 100 maka lebih baik diambil semua dan penelitian ini menjadi penelitian populasi. Dalam penelitian ini populasi dijadikan sampel penelitian, yang biasa disebut sampling jenuh atau total sampling. Metode pengambilan sampel pada penelitian ini ialah metode total sampling, yaitu semua anak diskalkulia kelas IV di SD N 01 Limau Manis Padang berjumlah tujuh anak. Tujuh anak ini terdiri dari 3 perempuan dan 4 laki-laki. Inisial dari masingmasing sampel penelitian diantaranya, GL, TR, ST, JW, RT, DF dan RM.

Pada penelitian ini instrumen penelitian yang digunakan yakni soal-soal pengurangan yang diberikan sebelum dan sesudah perlakuan. Setelah itu, teknik pengumpulan data pada penelitian ini ialah tes dengan alat pengumpulan datanya buti-butir soal dari tes tersebut. Tes berisikan 10 soal mengenai pengurangan dengan meminjam puluhan. Analisis data pada penelitian kuantitatif menggunakan metode statistik, dalam penelitian ini teknik analisis data menggunakan uji statistik dengan rumus uji Mann Whitney taraf signifikan $95 \%$ atau $\alpha=0,05$. Kriteria pengujian hipotesis adalah $\mathrm{H}_{\mathrm{a}}$ diterima jika $\mathrm{U}_{\text {hitung }}>$ $\mathrm{U}_{\text {tabel }}$ dan $\mathrm{H}_{0}$ diterima jika $\mathrm{U}_{\text {hitung }} \leq \mathrm{U}_{\text {tabel. }}$. 


\section{Hasil}

Data yang telah diperoleh dari nilai tujuh anak diskakulia kelas IV SD N 01 Limau Manis Padang. Materi yang diberikan ialah mengenai pengurangan puluhan dengan teknik meminjam. Saat dilapangan sesuai dengan teknik dan alat pengumpulan data, data diperoleh melalui tes tulisan didalamnya terdiri terdapat butir-butir soal mengenai pengurangan. Setiap tes yang diberikan berjumlah 10 soal tentang pengurangan. Data yang diolah berupa nilai pretest dan post-test yaitu menguji kemampuan awal subjek sebelum diberikan perlakuan dan kemampuan akhir setelah diberikan perlakuan menggunakan media puzzle kartu angka. setelah diperoleh nilai pretest dimasukan kedalam tabel, selanjutnya diberikan perlakukan menggunakan media puzzle kartu angka Terlihat adanya peningkatkan pada nilai evaluasi anak maka dapat diberikan tes akhir atau post-test. Nilai dari pretest dan post-test akan dimasukan ke dalam tabel, terlihat pada tabel dibawah ini, untuk $\mathrm{O}_{1}$ merupakan nilai pretest dan $\mathrm{O}_{2}$ merupakan nilai post-test.

Tabel 1. Nilai Pretest dan Nilai Post-test

\begin{tabular}{lccc}
\hline No & Nama Siswa & O⿻ $_{1}$ & O $_{2}$ \\
\hline 1 & GL & 0 & 80 \\
2 & TR & 0 & 70 \\
3 & ST & 0 & 60 \\
4 & JW & 0 & 80 \\
5 & RT & 0 & 70 \\
6 & DF & 0 & 60 \\
7 & RM & 0 & 70 \\
\hline
\end{tabular}

Telah terlihat dengan jelas nilai pretest dan post-test pada tabel tersebut. Nilai yang terdapat pada tabel diatas merupakan nilai anak diskalkulia untuk kemampuan pengurangan puluhan dengan teknik meminjam. Selanjutnya nilai akan diurutkan dari nilai tertinggi hingga nilai terendah. Setelah diurutkan akan diberikan peringkat pada setiap nilai dari nilai tertinggi hingga yang terendah. Hasilnya akan terlihat seperti tabel 2 dibawah ini, nilai pretest dan post-test dan peringkat masing-masing nilai.

Tabel 2. Data Analisis Rank

\begin{tabular}{lccc}
\hline No & Nama Siswa & Nilai & Rank \\
\hline 1 & GL & 80 & 1,5 \\
2 & JW & 80 & 1,5 \\
3 & TR & 70 & 4 \\
4 & RT & 70 & 4 \\
5 & RM & 70 & 4 \\
6 & ST & 60 & 6,5 \\
7 & DF & 6,5 \\
8 & GL & 60 & 11 \\
9 & TR & 0 & 11 \\
10 & ST & 0 & 11 \\
11 & JW & 0 & 11 \\
12 & RT & 0 & 11 \\
14 & DF & 0 & 11 \\
\hline
\end{tabular}

Kegiatan seelanjutnya setelag didapatkan peringkat masing-masing, maka jumlahkan peringkat pada hasil pretest dan peringkat pada hasil post-test. Terlihat pada tabel dibawah dijumlahkan sesuai dengan bagian untuk pretest dan bagian untuk post-test. Nilai pretest dan post-test diikuti dengan masingmasing rangkingnya, dan terlihat jumlah dari rangking tersebut, pada rangking pada nilai pretest dan rangking pada nilai post-test. 
Tabel 3. Perhitungan Rank

\begin{tabular}{|c|c|c|c|c|c|}
\hline No & Nama Siswa & $\overline{\mathbf{O}_{1}}$ & $\overline{\mathrm{O}_{2}}$ & $\mathbf{R}_{1}$ & $\mathbf{R}_{2}$ \\
\hline 1 & GL & 0 & 80 & 11 & 1,5 \\
\hline 2 & TR & 0 & 70 & 11 & 4 \\
\hline 3 & ST & 0 & 60 & 11 & 6,5 \\
\hline 4 & JW & 0 & 80 & 11 & 1,5 \\
\hline 5 & RT & 0 & 70 & 11 & 4 \\
\hline 6 & $\mathrm{DF}$ & 0 & 60 & 11 & 6,5 \\
\hline 7 & $\mathrm{RM}$ & 0 & 70 & 11 & 4 \\
\hline \multicolumn{2}{|c|}{ Jumlah } & & & 77 & 28 \\
\hline
\end{tabular}

Keterangan :
$\begin{array}{ll}\mathrm{O}_{1} & =\text { Hasil pretest } \\ \mathrm{O}_{2} & =\text { Hasil post-test } \\ \mathrm{R}_{1} & =\text { Peringkat hasil pretest } \\ \mathrm{R}_{2} & =\text { Peringkat hasil post-test }\end{array}$

Data jumlah rank atau peringkat pada hasil pretest dan hasil post-test telah didapatkan. Sehingga semua data yang diperlukan pada penelitian initelah dapatkan, secara ringkas seperti dibawah ini :

$\begin{array}{ll}\mathrm{R}_{1} & =77 \\ \mathrm{R}_{2} & =28 \\ \mathrm{n}_{1} & =5 \\ \mathrm{n}_{2} & =5\end{array}$

Maka gunakan rumus uji mann whihney untuk mengolah data. Sesuai denga rumus masukan setiap komponen data yang dibutuhkan. Dari hasil penghitungan maka didapat $U_{\text {hitung }}=49$ yang diambil dari hitungan yang terkecil, selanjutnya disesuaikan dengan $U_{\text {tabel }}$ pada taraf signifikan $95 \%$ dan $\alpha=$ 0,05 yaitu $=8$. Sehingga hasil yang diperoleh ialah $U_{\text {hitung }}=49$ dan $U_{\text {tabel }}=8$. Hasil pengujian hipotesis dengan $U_{\text {hitung }}=49$ dan $U_{\text {tabel }}=8$ didapat bahwa $\mathrm{U}_{\text {hitung }}>\mathrm{U}_{\text {Tabel}}$, hal ini menunjukkan $\mathrm{H}_{\mathrm{a}}$ diterima dan $\mathrm{H}_{\mathrm{o}}$ ditolak. Hasil penelitian ini adalah media puzzle kartu angka efektif dalam meningkatkan kemampuan pengurangan bagi anak diskalkulia kelas IV di SD N 01 Limau Manis Padang.

\section{Diskusi}

Berdasarkan permasalahan yang dilihat, kemampuan pengurangan anak dalam menyelesaikan soal pengurangan masih rendah. Pengurangan satuan anak bisa bahkan ketika terburu-buru anak masih salah. Ketika mengerjakan soal pengurangan meminjam anak membalikan angka dari pengurangan kecil ke besar menjadi besar ke kecil sehingga dalam penyelesaian tidak perlu meminjam. Pengurangan merupakan salah satu dari empat dasar aritmatika dengan mencari selisih suatu bilangan dengan bilangan lainnya. Konsep pengurangan seharusnya sudah anak kuasai dengan baik. Anak telah duduk dikelas IV, materi yang dituntut ialah perkalian, hingga operasi hitung campuran, sedangkan pengurangan saja anak belum menguasai.

Ditinjau dari pentingnya matematika dalam kehidupan sehari-hari, pengurangan merupakan konsep dasar dari matematika. Menurut Sukayati (2011:24) pengurangan merupakan kebalikan dari penjumlahan. Setelah anak diajarkan mengenai penjumlahan, menambah sesuatu akan dilanjutkan dengan materi pengurangan yaitu mengurangi. Ketika anak memiliki kesulitan dalam pengurangan, anak akan mengalami kesulitan dalam melakukan pembagian. Kemampuan berhitung merupakan kemampuan yang berlanjut, sehingga dari dasarnya seperti pengurangan akan berlanjut ke pembagian. Pada materi pengurangan terdiri dari pengurangan sederhana dan pengurangan yang membutuhkan bantuan dari angka didepannya seperti puluhan, pengurangan ini disebut pengurangan dengan meminjam (Gelar Dwirayahu dan Nursida, 2016:128).

Terlihat pada hasil yang anak peroleh pada nilai pretest sangat rendah, dikarenakan konsep dari pengurangan yang keliru terhadap anak. Dalam penelitian untuk membantu anak digunakan media agar anak dapat mengulang materi dan memahami pengurangan dengan baik. Media yang digunakan ialah media puzzle kartu angka. Maka perlakuan atau treatment yang akan dilakukan menggunakan media puzzle kartu angka dalam membantu meningkatkan kemampuan pengurangan anak diskalkulia.

Memberikan materi, menuntut guru untuk lebih bervariasi dalam mengajar agar anak dapat tertarik untuk belajar salah satunya dalam pelajaran matematika. Sudah menjadi problema bahwa anak-anak memandang matematika itu pelajaran yang sulit, sehingga anak malas dalam belajar menyebabkan anak tidak mengerti materi tersebut salah satunya untuk konsep dasar matematika. Anak tidak memperhatikan ketika guru mengajar, merasa sulit dalam belajar, bahkan enggan untuk mengulang materi. Salah satu komponen dalam proses belajar mengajar yaitu media pembelajaran. Berdasarkan hasil penelitian oleh Yamin tahun 2005 mengemukakan proses penyampaian informasi dengan teknik baru dan didukung dengan media pembelajaran akan menarik perhatian peserta didik untuk belajar. Guru yang dituntut untuk membuat media pembelajaran yang menarik perhatian anak, menyesuaikan dengan materi yang akan diajarkan, dan mempertimbangkan kondisi anak didiknya. Penelitian ini menggunakan media pembelajaran yang digunakan sesuai dengan penjelasan diatas ialah media puzzle kartu anak, permainanpuzzle yang dimodifikasi untuk membantu anak dalam mengatasi kesulitannya di pengurangan.

Media pembelajaran yang digunakan yaitu media puzzle kartu angka, membantu meningkatkan kemampuan pengurangan bagi anak diskalkulia. Menurut Rahayu (2010:76) Puzzle adalah permainan bongkar pasang yang dapat dikombinasikan dengan gambar-gambar yang disukai anak. Sejalan dengan itu Ismail (2009:199) puzzle adalah permainan yang menyusun suatu gambar atau benda yang telah dipecah dalam beberapa bagian. Salah satu contohnya yaitu alphabetic puzzle berbentuk teka-teki huruf, lalu ada body puzzle kepingan bagian-bagian tubuh. Dalam hal ini, puzzle dikombinasikan dengan kartu angka sehingga dapat menyelesaikan persoalan matematika terkait pengurangan. Kartu angka pada puzzle tersebut seperti kartu yang akan dipasangkann pada papan puzzle terdiri dari soal dan cara mengerjakan soal. Media Puzzle kartu angka merupakan sebuah alat dengan beberapa kartu angka yang bisa dibongkar dan dipasang kembali sesuai soal yang dikerjakan. Untuk bagian pertama itu untuk meletakkan kartu angka berupa soal bersusun pendek, lalu dibagian kedua merupakan penjabaran dari setiap angka pada soal bersusun panjang ditempatkan sesuai dengan nilai tempat. Media ini didasarkan pada materi pengurangan pada buku ajar yang digunakan oleh guru dalam pembelajaran matematika. 
Media puzzle kartu angka dapat membuat anak tertarik anak untuk belajar, karena media ini juga belum pernah digunakan oleh guru, dan dalam menggunakan anak akan seperti bermain menyusun kartu angka dipapan puzzle. Media ini layaknyapuzzle yang bisa dibongkar pasang kembali dengan isinya simbol angka sebagai alat hitung bagi anak dalam mengerjakan soal pengurangan teknik meminjam deret bawah. Kartu angka yang digunakan dapat bermacam-macam sesuai dengan soal yang diinginkan oleh guru. Media ini juga berupa permainan sehingga anak tertarik dalam menggunakannya. Selain itu membantu koordinasi mata dan tangan anak, kemampuan motorik halus, serta melatih kognitif anak.

Penelitian dilaksanakan di SD 01 Limau Manis Padang, pemberian pretest satu kali untuk melihat kemampuan awal anak sebelum diberikan perlakuan diperoleh nilai 0. Dari 10 soal yang diberikan semua anak salah dalam menjawab sehingga mendapatkan rata-rata nilai 0, dalam belajar guru hanya menggunakan media papan tulis. Anak menjawab semua soal dengan menguranginya membalik dari besar ke kecil sedangkan pada soal mengurangi dari kecil ke besar. Semua sampel yang diambil melakukan hal seperti itu, sehingga mendapatkan skor 0 pada lembar kerja. Hal ini disebabkan karena konsep pengurangan anak yang keliru, pengurangan kecil ke besar dibaliknya menjadi besar ke kecil, seperti 4 - 6 dibalik anak menjadi 6 - 4 sehingga anak mendapatkan jawaban 2. Materi yang diberikan mengenai pengurangan dengan teknik meminjam, karena anak mengerjakan pengurangan dengan membalik, sehingga tidak ada proses peminjaman dalam operasi hitungnya.

Selanjutnya diberikan pelakuan menggunakan media puzzle kartu angka sebanyak enam kali pertemuan. Pembelajaran menggunakan media puzzle kartu angka menyesuaikan kondisi anak, untuk pertemuan pertama, perkenalan dan satu soal diulang hingga anak memahami. Pertemuan kedua mulai soal-soal dibalik untuk melihat pemahaman anak, hingga pertemuan ketiga sampai keenam. Anak yang diajarkan sesuai dengan sampel penelitian berjumlah tujuh anak, dalam pelaksanaan perlakuan, ketika terlihat anak masih ragu maka anak akan maju untuk mencoba pengurangan dengan teknik meminjam menggunakan media puzzle kartu angka dengan diberikan penjelasan. Sebagai contoh hanya satu soal, selanjutnya anak mencoba soal yang lain, bahkan setiap anak mendapatkan soal yang berbeda. Masing-masing anak akan maju satu-persatu untuk melihat sejauh mana pemahaman anak. Setiap pertemuan diakhiri dengan evaluasi dengan 10 soal, untuk melihat adanya peningkatan pada pemahaman anak.

Terlihat pada hasil evaluasi, beberapa anak sudah stabil ada yang masih menurun terus meningkat kembali. Setelah adanya peningkatan yang signifikan, langkah selanjutnya yaitu post-test sebagai tes akhir untuk melihat kemampuan anak setelah diberikan perlakuan, dan diperoleh hasil rata-rata nilai 70. Secara garis besar semua anak sudah memahami konsep pengurangan dengan meminjam, dalam mengerjakan soal anak tidak membalik angka dari kecil ke besar menjadi besar ke kecil, sudah mengetahui adanya pinjaman pada puluhan. Tetapi terkadang anak masih lupa mengurangi karena adanya pinjaman pada puluhan, dan terkadang anak terburu-buru. Dapat dijelaskan anak sudah paham mengenai konsep pengurangan dengan meminjam.

Hasil yang anak peroleh pada pretest dan post-test terlihat adanya peningkatan yang terjadi pada nilai anak, dalam menyelesaikan soal pengurangan. Anak sudah memahami konsep dari pengurangan dengan teknik meminjam. Saat menggunakan media papan tulis hasil kemampuan anak masih rendah sedangkann menggunakan media puzzle kartu angka hasil anak yang peroleh mengalami kenaikan. Data yang telah diperoleh dianalisis sesuai dengan uji statistik yang digunakan ialah uji Mann Whitney. Pada hasil uji analisis data menggunakan uji Mann Whitney diperoleh hasil $\mathrm{U}_{\text {hitung }}=49$ diambil dari perhitungan terkecil dan $\mathrm{U}_{\text {tabel }}=8$ sesuai dengan taraf signifikan $95 \%$ dan $\alpha=0,05$. Sehingga hasil perhitungan menunjukkan bahwa $\mathrm{U}_{\text {hitung }}>$ $\mathrm{U}_{\text {Tabel. }}$ Berdasarkan pengujian hipotesis jika $\mathrm{U}_{\text {hitung }}>\mathrm{U}_{\text {Tabel }}$ didapatlah hasil yaitu $\mathrm{H}_{\mathrm{a}}$ diterima dan $\mathrm{H}_{\mathrm{o}}$ ditolak. $\mathrm{H}_{\mathrm{a}}$ dinyatakan dengan media puzzle kartu angka efektif dalam meningkatkan kemampuan operasi pengurangan bagi anak diskalkulia kelas IV SD N 01 Limau Manis Padang.

Berdasarkan analisis data yang telah peneliti olah dan jabarkan diatas, terbukti bahwa pemberian perlakuan menggunakan media puzzle kartu angka dapat meningkatkan kemampuan pengurangan dibandingkan media papan tulis bagi anak diskalkulia kelas IV SD N 01 Limau Manis Padang sesuai dengan teori oleh Lestari, dkk (2014:3) media puzzle angka dapat meningkatkan minat anak untuk melatih kemampuan kognitif khususnya dalam pengenalan bilangan. Ditinjau dari fungsi media pun, Menurut Miftah (2013:100) ada enam fungsi media, yaitu (1) membangkitkan motivasi belajar, (2) mengulang apa yang telah dipelajari, (3) menyediakan simulasi belajar, (4) mengaktifkan respon anak, (5) memberikan umpan balik dengan segera, dan (6) mengalakkan latihan yang serasi.

Selain itu ditinjau dari meningkatkan kemampuan pengurangan sesuai dengan teori oleh Runtukahu (2014:111) operasi pengurangan harus dikenalkan dengan pengalaman konkret, model kegiatan yang menggunakan objek-objek yang dapat dimanipulasi dan penggunaan bahasa informal baru beralih pada bahasa formal. Pengunaan bahasa yang mudah dimengerti oleh anak dan model kegiatan bisa berupa permainan yang dimodifikasi agar membantu motivasi anak untuk belajar.

\section{Kesimpulan}

Berdasarkan hasil penelitian ini yaitu media puzzle kartu angka efektif dalam meningkatkan kemampuan pengurangan bagi anak diskalkulia kelas IV SD N 01 Limau Manis Padang. Hal ini telah ditunjukkan pada hasil perhitungan data yang diolah menggunakan rumus uji Mann Whitney dengan hasil $U_{\text {hitung }}=49$ diambil dari nilai hitungan terkecil dan $U_{\text {tabel }}=8$ disesuaikan denga taraf signifikan $95 \%$ dan $\alpha=0,005$. Menunjukkan $U_{\text {hitung }}>U_{\text {tabel }}$ dengan hasil $\mathrm{U}_{\text {hitung }}=49>\mathrm{U}_{\text {tabel }}=8$. Penelitian ini menunjukkan, yang pertama,saat menggunakan media papan tulis, nilaites kemampuan pengurangan dengan teknik meminjam anak masih rendah. Kedua, ketika dibantu menggunakan media puzzle kartu angka, nilaites kemampuan pengurangan dengan teknik meminjam anak mengalami kenaikan. Sesuai dengan hasil pengujian hipotesis maka $\mathrm{H}_{\mathrm{a}}$ akan diterima jika $\mathrm{U}_{\text {hitung }}>\mathrm{U}_{\text {tabel }}$ dan dapat disimpulkanH $\mathrm{H}_{\mathrm{a}}$ diterimadengan media puzzle kartu angka efektif daripada media papan tulis dalam meningkatkan kemampuan pengurangan bagi anak diskalkulia kelas IV SD N 01 Limau Manis Padang.

Berdasarkan kesimpulan dari penelitian ini, maka saran untuk para pendidik agar lebih memperhatikan layanan yang diberikan kepada anak diskalkulia, sehingga membantu anak memahami materi yang anak belum kuasai. Dan kepada para peneliti untuk selanjutnya agar bisa dapat lebih kreatif, inovatif, dan variasi dalam membantu anak diskalkulia, baik dari media pembelajaran, startegi pembelajaran, metode pembelajaran, komponen dalam pembelajaran dapat menarik perhatian anak dan memudahkan anak dalam belajar.

\section{Daftar Rujukan}

Ismail, A. (2009). Education Games. Yogyakarta : Pro-U Media.

Lestari, Ni Komang Ayu Sri., Raga, Gede., Sudatha, Ghe Wawan. (2014). Penerapan Metode Bermain Berbantuan Media Puzzle Angka Untuk Meningkatkan Kemampuan Kognitif Dalam Pengenalan Bilangan. Jurnal PGPAUD Universitas Ganesha (Volume 2 Nomor 1). 2-3.

Miftah, M. (2013). Fungsi dan Peran Media Pembelajaran Sebagai Upaya Peningkatan Kemampuan Belajar Siswa. Jurnal KWANGSAN (Volume 1 Nomor 2). 100.

Prabowo, Rendra Ari. (2012). Penggunaan Media Puzzle Untuk Meningkatkan Hasil Belajar Pada Mata Pelajaran IPA di Kelas V SDN 1 Jatipurwo. Skripsi Tidak di Terbitkan. Universitas Muhammadiyah Surakarta.

Rahayu. L. (2010). 20 Fun Activitis For Toddler. Surakarta : Indiva Media Kreasi.

Runtukahu, Tombokan J. \& Selpius Kandou. (2014). Pembelajaran Matematika Dasar Bagi Anak Berkesulitan Belajar. Yogyakarta : Ar-Ruzz Media.

Shadiq, F. (2004). Pemecahan Masalah Penalaran dan Komunikasi. Yogyakarta : PPPG Matematika.

Shalev RS, Manor O, Gross-Tsur V. (2005). Developmental dyscalculia: a prospective six-year follow-up. Developmental Medicine Child Neurology. 47(2):121-5.

Sofa, S. (2015). Penerapan Media Puzzle Cerdas Untuk Meningkatkan Kemampuan Kognitif Anak Taman Kanak-Kanak dalam Berhitung. Jurnal 
Pedagogi (Volume 1 Nomor 1).

Sukayati, (2011).Pembelajaran Pecahan di Sekolah Dasar. Yogyakarta : Widyaiswara PPPPTK Matematika.

Suryani, Yulinda Erma. (2010). Kesulitan Belajar. Jurnal Magistra (Nomor 73 Th XXII).

Turmudi. (2008). Landasan Filsafat dan Teori Pembelajaran Matematika (Berparadigma Eksploratif dan Investigatif). Jakarta : Leusur Cita Pustaka.

Widyarahyu, G \& Nursida. (2016). Mengembangkan pembelajaran Matematika dengan Metode Permainan Untuk Siswa kelas 1 MI.Jurnal Pendidikan dan Pendidikan Matematika (Volume 5 Nomor 2). 128.

Yamin, M. (2005). Strategi Pembelajaran Berbasis Kompetensi. Jakarta : Gaung Persada. 